


\section{A Plural Century: \\ Situating Interculturalism and Multiculturalism}

Nasar Meer, Tariq Modood and Ricard Zapata-Barrero

\section{Introduction}

This book explores the topics of interculturalism and multiculturalism, including their relationships to each other and to public philosophies more broadly. In many respects it is a timely and perhaps overdue intervention that locates the debate about interculturalism and multiculturalism in amongst a series of sociological and political developments. It is widely accepted that the significant movement and settlement of people outside their country of birth 'is now structurally embedded in the economies and societies of most countries' (Pécoud and de Guchteneire argue, 2007: 5). The prevailing context is that the majority of the world's population resides in one hundred and seventy five poorer countries relative to the wealth that is disproportionately concentrated in around twenty. With levels of migration fluctuating but anxieties constant, it is common to hear governments and other agencies favour 'managed migration' and strategies for 'integration' which, though meaning different things in different places, registers migration and post-migration settlement as an intractable feature of contemporary society.

As we show below, this has immediate implications for the approaches that interculturalists and multiculturalists adopt, but this sociological development is matched by a political tendency, in so far as any story of the 'plural century' cannot be restricted to migration only, and must also take account of what we might think of as state re-making. One illustration is 
found in modes of sub-state national and federal governance that resist the drive for a unitary and centralised state citizenship, and so challenge how one 'dominant group organises the common life in a way that reflects its own authority and culture' (Walzer, 1997: 25; cf., Hepburn and Zapata-Barrero, 2014). Large territorially concentrated communities who see themselves as autonomous nations within nation-states are the most obvious example of this. Despite what is sometimes claimed therefore, these remind us that all of today's nation-states reflect some longstanding internal diversity (not withstanding what status non-majority cultural forms may have enjoyed). A second form of state-remaking has less to do with territory and autonomy and more to do with overarching collective membership. This is about legal rights but also about symbols and political equality and remaking citizenship to include 'difference'. What it shares with first the expression of state remaking flows from an underlying concern that minorities will 'feel crucially left out [when] the majority understand the polity as an expression of their nation, or agreed purpose, whatever it may be' (Taylor, 2001: 123). In this respect it is striking that there seems to be greater minority integration in countries with more multiculturalist policies than in those with none. So controlling for other factors, when the same ethnic minority group (with the same pre-arrival characteristics) enters two different countries at the same time, it has been shown that the group who are in the multicultural context fares much better (Bloemraard, 2006). ${ }^{1}$

\footnotetext{
${ }^{1}$ In her study, Bloemraard (2006) compared the integration of two Vietnamese groups in Toronto and Canada respectively, and then repeated this for Portuguese minorities. According to Kymlicka (2012: 46), in these cases Canada's proactive multicultural policies 'sent a clear message that Vietnamese [and Portuguese] political participation is welcome, and have also provided material and logistical support for self-organization and political representation of the community'. Elsewhere, Berry et al. (2006) use the International Comparative Study of Ethnocultural Youth (which focuses on thirteen countries and takes in 5000 young people) to argue that polices and discourses of multiculturalism (e.g. plural national identities, equal opportunity monitoring, effective anti-discrimination legislation and enforcement) encourage a more successful and deeply established integration in those settings. In the British case, this is supported by Heath and Roberts (2008: 2), who in their analyses of the UK Government's Citizenship survey, report: 'We find no evidence that Muslims or people of Pakistani heritage were in general less attached to Britain than were other religions or ethnic groups. Ethnic minorities show clear evidence of 'dual' rather than
} 
Taken together, what we describe further complicates long established tensions 'between the universalistic principles ushered in by the American and French Revolutions and the particularities of nationality, ethnicity, gender, 'race', and language' (Benhabib, 2002: vii). The point being that all liberal democratic citizenship has been cut from a cloth coloured by prevailing national cultures and identities, and new modes of citizenship have developed that seek to correct this. In their own ways both interculturalists and multiculturalists offer such a move, and both register 'a third generation norm of legitimacy, namely respect for reasonable cultural diversity, which needs to be considered on a par with the [first and second generation] norms of freedom and equality, and so to modify policies of 'free and equal treatment' accordingly' (Tully, 2002: 102). While different political contexts express distinct stories, something that is emphatically brought out in the proceeding focus between post-migration multicultural settlements and the status of nationalist settlements respectively, both interculturalism and multiculturalism seeks to be a vehicle for what Tully (2001: 25) calls 'citizenization' - the processes of incorporation into and (as a consequence) revision of prevailing citizenship settlements.

It is against this background that our concepts of interculturalism and multiculturalism have developed their normative and political content. While this content unfolds throughout the rest of the introduction and indeed the book more broadly, it would be useful at this juncture to provide a pocket overview of how we understand the provenance of each. For the purposes of our discussion, interculturalism's core meaning refers to support for crosscultural dialogue. Bouchard and Taylor (2012: 118) state that the first record of the term 'Interculturalism' in Quebec is in 1985 and prior to which they could only find two references, a Council of Europe and a Belgian government document, both dated 1981. It is

\footnotetext{
'exclusive' identities.' They point instead to hyphenated identities, in showing that 43 per cent of Muslims belong 'very strongly' to Britain and 42 per cent say that they belong to Britain 'fairly strongly', and taken together these figures are higher for Muslim respondents than they are for Christian ones and those of 'no religion' (for an overview of some recent studies see Meer, 2014: 889 and Modood, 2013: 145).
} 
worth noting that also that 'intercultural education' was being used by Germans and others from the late 1970s (Krauss and Schonwalder, 2006) and also seems to have European origins and of the same vintage as 'multicultural education', while the first documented uses of the term 'intercultural' in Latin America may have been in Venezuela's 1979 bilingual intercultural education policy (see Solano, this volume). In Canada meanwhile interculturalism developed as a reaction to the multiculturalism of Federal Canada (see Gagnon and Iacovino, this volume), in Europe it has emerged as a city policy strategy in the Intercultural cities program of the Council of Europe in 2008. On 15th January 2015 the Committee of Ministers of the Council of Europe adopted a recommendation on the Intercultural cities approach, recognizing it as a way forward and recommending it to cities and governments. ${ }^{2}$ Multiculturalism meanwhile, and although used differently across varying contexts, has more broadly been focused on the accommodation and integration of migrant and post-migrant groups typically termed 'ethnic minorities'. To confuse matters however, multiculturalism has also taken in multinational questions - for example, multiculturalist Canada focused from the outset on constitutional and land issues too. To further narrow the conceptual span of multiculturalism, Laegaard (2014) has recently argued that Euro-multiculturalism is a useful differentiation to the other modes (cf Triandafyllidou, Modood and Meer, 2013), but we might nonetheless summarize that multiculturalism can simultaneously describe:

the political accommodation by the state and/or a dominant group of all minority cultures defined first and foremost by reference to race or ethnicity, and, additionally but more controversially, by reference to other group-defining characteristics such as nationality, aboriginality, or religion. The latter is more controversial not only because it extends the range of the groups that have to be accommodated, but also because it tends to make

\footnotetext{
${ }^{2}$ See Recommendation CM/Rec(2015)1 of the Committee of Ministers to member States on intercultural integration. Available at: https://wcd.coe.int/ViewDoc.jsp?Ref=CM\%2FRec\%282015\%291\&Language= lanEnglish\&Ver=original \&Site $=C M \& B a c k C o l o r l n t e r n e t=C_{3} C_{3} C_{3} \&$ BackColorlntranet $=E D B 021 \& B a c k$ ColorLogged $=\mathrm{F}_{5} \mathrm{D}_{3} 83$ \# (accessed January 2015).
} 
larger political claims and so tends to resist having these claims reduced to those of immigrants. (Modood and Meer 2013: 113)

In ways that have both overlapped and diverged therefore, both interculturalism and multiculturalism is seeking to engender certain kinds of unity in polities that have seen what Arnold Toynbee (1958: 87) termed 'the annihilation of distance'. This problematic emerges across a multifaceted set of arguments presented throughout the chapters in this book, and takes up intellectual and policy debates that span Europe, and South and North America.

\section{Debating the Dividing Lines}

This book is presented in the context of a widespread (but contested) view that there has been a retreat from relatively modest approaches of multicultural citizenship across a variety of citizenship regimes (Meer, Mouritsen, Faas and de Witte, 2015). The reasons are various, but include how for some, multiculturalism has facilitated social fragmentation and entrenched social divisions, for others it has distracted attention away from socio-economic disparities or encouraged a moral hesitancy amongst 'native' populations. Some even blame it for international terrorism (Phillips, 2006; Prins and Salisbury, 2008). While the theory and practice of interculturalism has its own provenance too, especially outside English speaking contexts such as in Latin American debates about interculturalidad (see SolanoCompas this volume and Tubino, 2013) and Québec scholarship about distinguishing it from Federal multiculturalism (see Bouchard this volume), it has become especially prominent as a distinct alternative to prevailing approaches of multiculturalism in Europe. As Irena Guidikova (2011: 4), coordinator of the Intercultural Cities Program 3 puts it, multiculturalism 'is increasingly being challenged as eroding the foundations of community

\footnotetext{
${ }^{3}$ A pilot programme of the Council of Europe jointly with the European Commission that examines practical tools for the management of interculturalism in 11 European towns and cities.
} 
cohesion and the universality of human rights and equal dignity, and accused of being unable to forge a common identity'. ${ }^{4}$ For Zapata-Barrero (this volume) too, interculturalism 'enters into this negative diagnosis of Mc [multiculturalism], offering a lifeline'. While advocates of both are in favour of recognising and accommodating diversity, interculturalists arguably share the view that interculturalism, minimally, addresses multiculturalist shortcomings, and in stronger versions no longer sees multiculturalism as a persuasive intellectual approach or policy goal. For example, one of the leading advocates and policy practitioner of 'community cohesion', Ted Cantle (2012: 2), has described interculturalism 'as an opportunity to replace multiculturalism as a conceptual and policy framework'. Others such as Maxwell et al. (2012: 429) maintain that interculturalism represents a gain over Multiculturalism while pursuing the same set of mostly uncontroversial political ends' (see also Cantle this volume).

Outside academic quarters, the Council of Europe's (2008) White Paper on intercultural dialogue, Living together as Equals in Dignity, includes reports that practitioners and NGOs across Europe have come to the conclusion that multiculturalism is no longer fit for purpose and needs to be replaced by a form of interculturalism. Similar views were expressed in the UNESCO World Report, Investing in cultural diversity and intercultural dialogue (2008). The former report facilitated the creation of the Intercultural Cities program (CofE, 2013), which seeks 'a strategic reorientation of urban governance and policies to encourage adequate representation, positive intercultural mixing and interaction, and institutional capacity to deal with cultural conflict' (Guidikova, 2014: 1). As is stated in its founding documents, placing emphasis on the fact that IC is basically seen as a local and especially city-level means of responding to diversity (Zapata-Barrero, 2015). In this framing, '[o]ne of the defining factors that will determine, over coming years, which cities flourish and which decline will be the extent to which they allow their diversity to be their asset... Whilst

\footnotetext{
4 http://www.coe.int/t/dg4/cultureheritage/culture/Cities/Publication/BookCoEo6-Guidikova.pdf
} 
national and supra-national bodies will continue to wield an influence it will increasingly be the choices that cities themselves make which will seal their future' (Council of Europe 2008, 22). The British Council (quoted in Phipps, 2014: 109) too has insisted in the need for interculturalism, specifically in order to 'develop a deeper understanding of diverse perspectives and practices; to increase participation and the freedom and ability to make choices; to foster equality; and to enhance creative processes'.

Despite the fact that the evidence is that there has not been a wholesale or even a significant retreat from multiculturalism, ${ }^{5}$ statements such as these above have invited the question: how are interculturalism and multiculturalism similar or different, substantively or otherwise, from each other? In this collection we bring together two otherwise parallel - but largely unrelated - attempts to answer this question. The first centres not in Europe but in North America, and especially surrounds the Consultation Commission on the Accommodation of Practices Related to Cultural Differences, commissioned by the Québec Government, widely known as the Bouchard and Taylor report(2008). This maintains that Quebec as a nation has developed a distinctive intercultural approach to diversity that is quite distinct to Federal Canadian multiculturalism. As one of the authors of the report puts it, 'The crucial point here is that there really is a majority culture within the nation of Quebec whose fragility is a permanent fact of life. This results in a specific vision of nationhood, identity and national belonging.' (Bouchard, 2011: 463 See also Bouchard this volume) Thus

\footnotetext{
${ }^{5}$ For example, if we take two countries seen as multiculturalist (the UK and the Netherlands) and two countries that are not seen as multiculturalist (Denmark and Germany). Using Banting and Kymlicka's (2013, pp. 7-8) Multiculturalism Policy Index, which monitors multicultural public policies across 21 Western democracies across three intervals (1980, 2000, and 2010), we see that that in 2000 , the Netherlands and Britain scored 5.5 and 5.5 out of a possible 8, respectively, and Denmark and Germany scored 0.5 and 2, respectively. By 2010, the score for the Netherlands had been reduced to 2, Britain remained the same, Denmark was at o, and Germany had increased to 2.5 . This offers a mixed picture of the fate of multiculturalism that is given qualitative support in Vertovec and Wessendorf's (2010) reading that while the term multiculturalism has 'disappeared from the political rhetoric' (p. 18), this is something that is not paralleled by the 'eradication, nor much to the detriment, of actual measures, institutions, and frameworks of minority cultural recognition' (p. 21).
} 
while multiculturalism remains the official policy of the Canadian Federal government, named as such in section 27 of the Canadian Charter, 'all Quebec governments since 1981, as well as the Quebec population in general, have rejected it' (Tremblay, 2009: 2).

In important respects the Quebec case begins to explain how the normative debates around interculturalism and multiculturalism have been quite political and less about normative practice. One of the contributions of this book therefore is to bring more contextualized policy concerns into view. For in Europe, meanwhile, the concept of interculturalism is now found in places as diverse as German, Greek and Italian education programmes (Luctenberg 2003; Potero, 2012), Spanish urban governance (a Spanish network of Intercultural cities was created in 20116); Belgian commissions on cultural diversity; and Russian teaching on world cultures (Froumin 2003), and is principally oriented toward addressing questions of migration related diversity. A prominent symbolic example could be how 2008 was designated as the European Year of Intercultural Dialogue (EYID), with the European Commission's stated objective being to encourage 'all those living in Europe to explore the benefits of our rich cultural heritage and opportunities to learn from different cultural traditions'. The aforementioned Intercultural Cities program places emphasis on interculturalism as an integration policy (Guidikova, 2015), and a way to manage city-level public spaces (Wood, 2015). It was nurtured in management and urban studies on diversity, focusing on policy and implementation (Zapata-Barrero, 2015b), and assumed that diversity is itself a culture that should be promoted through an intercultural strategy (Zapata-Barrero, 2015a).

In both cases, although expressed differently, advocates of interculturalism wish to emphasize its positive qualities in terms of addressing a gap that multiculturalism allegedly

\footnotetext{
${ }^{6}$ See www.ciudadesinterculturales.com/
} 
misses. Multiculturalists have in turn responded to this characterization by re-stating what multiculturalism is (see Meer and Modood this volume) and challenging the argument that interculturalism offers a substantive advance. Outside of Canada, which we have already noted, in the USA, UK and later the Netherlands, respectively, multiculturalism was initially centred on issues of schooling, both in terms of the curriculum and as an institution, to include features such as minority languages, non-Christian religions and holidays, halal food, dress and so on. In this respect there was ambition to remake the common institution and curriculum to include minorities too. This became married to a parallel equality focus that had a civil rights provenance, and which together developed more broadly into the contemporary meaning of multiculturalism as a critique of 'the myth of homogeneous and monocultural nation-states' (Castles 2000: 5), and an advocacy of the right of minority 'cultural maintenance and community formation, linking these to social equality and protection from discrimination' (ibid.). The political multiculturalism of Modood (2006: 61), for example, insists that 'when new groups enter a society, there has to be some education and refinement of...sensitivities in the light of changing circumstances and the specific vulnerabilities of new entrants' (2006: 61).

Multiculturalists however argue that much of this is consistent with interculturalist objectives. Kymlicka (this volume) presents an especially challenging response: 'The interculturalism-as-remedy-for-failed-multiculturalism trope is not offered as an objective social science account of our situation, but rather, I believe, is intended to serve as a new narrative, or if you like, a new myth.' A series of debates have therefore emerged but too often these have remained spatially restricted to either Europe or North America, and so are rarely bridged and connected to each other, or are restricted to broad categories which locate interculturalism and multiculturalism in, for example, a 'duality' and 'diversity' paradigm respectively (Bouchard, this volume). This means that while the intercultural-multicultural foundational debate is now widely established, there remains untapped potential for 
intellectual dialogue and policy engagement for audiences across (and also within) both approaches. This edited collection addresses this gap by engaging with real world cases that moves us beyond pure theory to ask: 'what are the dividing lines between interculturalism and multiculturalism?' Let us begin with where there is agreement:

- Firstly, both interculturalism and multiculturalism register not only the undeniable fact of cultural pluralism but see this as an asset even while each is committed to reconciling this diversity with unity

- Secondly, each has a shared adversary in assimilationist and unreconstructed ideas of membership and policy perspectives concerning citizenship

- Thirdly, there is a common aversion to formalist (or deontological) notions of liberalism that do not take into consideration the role and function of culture and identity

- Fourthly, each seeks to remake the terms of fair and equal treatment through the inclusion of cultural difference.

Where there appears to be more tension is explicitly taken up in the various chapters that follow and can perhaps also be identified in terms of four themes:

- Firstly, the status of dialogue, contact and interpersonal relations within respective approaches

- Secondly, the position of historical majority cultural forms - or majority precedence

- Thirdly, the normative significance of recognising groups in addition to individual citizens

- Fourthly, the status of minority religious communities and organisations. 
On the second issue, Bouchard (2011: 438) usefully summarises how: interculturalism concerns itself with the interests of the majority culture, whose desire to perpetuate and maintain itself as perfectly legitimate, as much as it does with the interests of minorities and immigrants'. In this respect interculturalism addresses multiculturalism's alleged asymmetry in focusing only on the 'minority'. What is interesting is that this broadly stays within conventional parameters e.g., it is not only liberal nationalists who think that historical 'elective affinities' (Canovan, 1996) mean nation-states are the best guarantors of a type of liberal citizenship. While multiculturalists too want to retain the link between culture and citizenship, they would seek to remake both (see Levey this volume and Modood, this volume) In relation to the third issue, the status of groups, as Meer and Modood (this volume) show, some interculturalists are more hostile to the recognition of minority group claims (indeed to group categories more broadly). This is clearly expressed in this volume by the chapter from Ted Cantle and elsewhere by Robin Cohen (2013) amongst others. Ricard Zapata-Barrero (this volume) also argues that a prevailing differentia of interculturalism (from multiculturalism) is that the former priorities individual overt group rights. Yet it is easily shown that other interculturalists, such as Gagaon and Iacovino (this volume) and Bouchard (this volume) want to build around groups and nations. In relation to the fourth issue of disagreement, the orientation towards the ethnoreligious, interculturalists broadly do not include religious groups within their framework, preferring to leave new religions to prevailing approaches of toleration within existing secularist arrangements. However, on this some interculturalists and some multiculturalists complement each other. Kymlicka's liberal secularism, for example, is quite consistent with this view (Meer and Modood, forthcoming). Turning in detail to the first issue of contention, the status of dialogue and contact for interculturalists, the argument is best put by Zapata-Barrero (this volume), to whom

the core of intercultural citizenship is essentially one basic idea: that the interaction among people from different diversity attributions matters, and that this has been overlooked by the multicultural citizenship paradigm, which has mainly concentrated on ensuring the cultural rights of diverse groups. 
To explore both issues further the next section of this introduction locates both intercultural and multicultural concerns within the wider intellectual landscape. The important point to bear in mind at the outset, however, and as the subsequent chapters betray, is that neither interculturalists nor multiculturalists occupy a position of unanimity amongst themselves, and interculturalists and multiculturalists can and do agree. A good place to begin to understand why concerns the common denominator of the role and nature of pluralism; something that has both shared and diverging implications for interculturalism and multiculturalism, and it is to this we next turn.

\section{Inter- and multi- cultural pluralism}

The fact of pluralism, to paraphrase Rawls, emerges as self-evident in a world comprising over six hundred languages, five hundred ethno-cultural groups, and innumerable religions

spread across nearly two hundred recognized sovereign states. By definition therefore pluralism is an inescapable feature of human societies, and 'can neither be wished out of existence nor suppressed without an unacceptable degree of coercion, and often not even then' (Parekh, 2000: 196). Different kinds of polities have long struggled with reconciling cultural pluralism with an idea of collective membership. In one respect this is odd because the intermingling of cultural (including religious and ethnic) diversity is as old as we can record. On the other hand it may well be anticipated that un-settling established social and identity configurations creates challenges, something that is no less apparent in modern polities. The way pluralism is conceived obviously has implications for understanding the relationships between interculturalism and multiculturalism and other ways of reconciling unity and diversity. Minimally, we might build on the distinction Isaiah Berlin (1991: 10) put forward between pluralism and relativism. While the latter flattens out our capacity to make value judgments, according to Berlin, the former retains this capacity but anchors it in an ability to imagine and empathize with that which is different to us. He elaborates: 
Members of one culture can, by the force of imaginative insight, understand... the value, the ideals, the forms of life of another culture or society, even those remote in time or space. They may find these values unacceptable, but if they open their minds sufficiently they can grasp how one might be a full human being, with whom one could communicate, at the same time live in the light of values widely different from one's own, but which nevertheless one can see to be values, ends of life, by the realization of which men could be fulfilled.

This value pluralism can endow agents with a capacity to see the world from different vantage points, which is quite different to how pluralism is sometimes understood as, say, a set of governmental approaches. The latter are not purely theoretical, though they take in theory, but instead centre on an understanding of democracy as a competition between rival elites (Dahl 1961), or a conception of organized groups which form a link between the governed and representative government (Bentley 1948). In Berlin's statement, in contrast, pluralism bestows a certain insight into real and imagined cultural differences, ways of life and forms of social organization.

\section{Contact and Dialogue}

This insight is not neutral, that is to say that it is not without judgment on our part, but is nonetheless able to register a utility in different approaches. Our interest here primarily concerns how both interculturalism and multiculturalism appeal to a common register of pluralism on which contact and dialogue contact can proceed. In one respect this is an obvious ambition. As Carbaugh (2013: 10) asks: 'Who, indeed, would be against "dialogue”?' The challenge is surely to make an abstract ambition not only operable but also politically meaningful. Dialogue, to paraphrase Augustine on charity, is no substitute for justice. And the complaint arises that in recent years we have seen a significant intellectual investment in dialogue in a manner that is sometimes uncoupled from wider political contexts (see Phipps, 2014). Differences in status and power relations more broadly mean that dialogue(s) do not proceed on an equal footing, can easily imply what Young (1990: 165) called 'coming to the game after it is already begun, after the rules and standards have been set, and having to 
prove oneself accordingly'. This of course spills over into the manner in which different kinds of contact can proceed. As Pettigrew et al., (2011: 277) argue:

Not all intergroup contact reduces prejudice. Some situations engender enhanced prejudice. Such negative intergroup contact has received less research attention... Negative contact typically occurs in situations where the participants feel threatened and did not choose to have contact. These situations frequently occur in work environments where intergroup competition exists as well as in situations involving intergroup conflict.

As Zapata-Barrero argues (this volume), contact and dialogue is understood in functional terms as 'interaction', defined roughly as acting together, sharing a public sphere and working for some common purpose, and he extensively deals with the place of 'interaction' in founding several strands within interculturalism. A compelling attempt to bring pluralism and dialogue together is once more found in Parekh's (2000: 167) argument. Here the intrinsic value of pluralism lies in how cultures other than one's own have something to teach us, such that members of minority cultures should be encouraged to cultivate their moral and aesthetic insights for humanity as a whole. He offers the following explanation:

Since human capacities and values conflict, every culture realizes a limited range of them and neglects, marginalizes and suppresses others. However rich it may be, no culture embodies all that is valuable in human life and develops the full range of human possibilities. Different cultures thus correct and complement each other, expand each other's horizon of thought and alert each other to new forms of human fulfillment. The value of other cultures is independent of whether or not they are options for us...inassimilable otherness challenges us intellectually and morally, stretches our imagination, and compels us to recognize the limits of our categories of thought.

Going further than Berlin's 'imaginative insight', Parekh uses the idea of intercultural dialogue as a basis to widen the horizons of our thought or of a way of life. Moreover, Parekh thinks dialogue rather than an appeal to universal truths is the way to handle multicultural conflicts like those over free speech and protecting minorities from demeaning speech, or the 
virtues of exclusively legalised monogamy over the inclusion of polygamy. This can be contrasted to rationalist conceptions of dialogue. In the latter camp Habermas (1987), most prominently, deems dialogue as powerful regulative ideal that appeals to reason and reciprocity rather than equality per se. What this under-emphasises in practice are existing and entrenched hierarchies (and more broadly suffers from problems of abstractness). In contrast, dialogue for both interculturalists and multiculturalists is 'bi-focal' (Parekh, 2000: 271) in so far as it centres on both 'the minority's and wider society's way of life'). Whilst multiculturalists like Parekh make intercultural dialogue at philosophical and political levels central to their theories, interculturalists have offered an alternative, dialogue in terms of local encounters. Here, then, seems a perfect example of where the multiculturalists and interculturalists usefully complement each other, even if the latter sometimes believe that the emphasis on dialogue is an interculturalist innovation (see Modood, this volume, and Levey, this volume). One possible explanation for this characterisation is that sustaining a minority language has been central where interculturalism has developed; this is certainly the case in minority nations such as Quebec and Catalonia, and this is also true of Latin America where Intercultural Bilingual Education has been a key element of interculturalidad.

\section{Groups and Nations}

At this juncture some interculturalists and multiculturalists diverge on the status of historical majorities for, as Modood (2014: 306 and this volume) observes, the intercultural 'emphasis on majoritarian anxieties is a radically different starting point from multiculturalism'. Perhaps this is best brought out not by comparing multiculturalism and interculturalism, but by two forms of the latter. Here we find a marked divergence between Quebec and European interculturalism. The former makes a moral and policy case for the recognition of relatively distinct sub-state nationalisms (see Gagnon and Iacovino and also 
Bouchard this volume). Gagnon and Iacovino, for example, contrast interculturalism positively with multiculturalism in a way that relies upon a strong formulation of groups, yet for Cantle (this volume), this 'mirrors much of the reified, static and defensive form of identity management found in European forms of multiculturalism'. That Quebec has developed a distinctive intercultural political approach to diversity in opposition to federal Canadian multiculturalism, however, is now a widely established argument. As Bouchard neatly summarises:

\begin{abstract}
Since the middle of the nineteenth century, francophones in Quebec have fought to gain acceptance of the idea that Canada is composed of two nations (Anglophone and Francophone). This vision of the country was undermined by the introduction of multiculturalism, which made francophones in Quebec simply one ethnic group among others throughout Canada. In this sense, multiculturalism weakened Quebec and for this reason it is the source of keen opposition from the francophone population). (Bouchard, 2011: 462).
\end{abstract}

This framing and the wider distinction between Quebec interculturalism and Canadian multiculturalism is certainly a contested one (see Kymlicka this volume), and might be illustrative of the difference between what Levey (this volume) sees as 'hard' and 'soft' distinctions. Quebec interculturalists insist that there should be a public space and identity that is not merely about individual constitutional or legal rights, and this public space is an identity for those who share it and so qualifies and counter-balances other identities valued by citizens. So far so Republican. The important point is that this is deemed to have an inescapable historical character, such that Quebec, and not merely federal Canada, is an object to which immigrants need to have identification with and integrate into, and should seek to maintain Quebec as a nation and not just a federal province.7 While for some Quebec is a nation within federal Canada, this interculturalism argument is not predicated on minority nationalism or multi-nationalism, but on a paradigm of minority-majority relations that are applicable to any nation and certainly would be asserted in an independent mono-

\footnotetext{
7 The same point may apply in other multi-national states, but there are different degrees and variations of 'multi-nationalism'.
} 
national Quebec. As such, and quite unlike their European counterparts (see Cantle, and Zapata-Barrero this volume), Quebec interculturalists are not minded to begin with the diversity of the location that migrants and ethnic minorities are from, or the superdiversity that this is alleged to cultivate therein. Guidikova (2014: 14), for example, insists that interculturalism in its European moulds thrives on a dynamic and constantly changing environment in which individuals and collectives express multiple, hybrid and evolving identities and needs'. This is very different to sustaining and elevating historically sedimented ad hoc majority precedence.

The difference between the two types of interculturalism bears resemblance instead to how Levey (this volume) draws out the differences between 'parity multiculturalists' and 'liberal nationalist multiculturalism' which, as he understands it, turns on the treatment of majority cultures. On this view since a Rawlsian neutral state organised by liberal principles alone is impossible, the best means of achieving liberal goals, including personal liberties, autonomy, freedom for cultural diversity, liberal constitutionalism and the welfare state, is through the stable basis of a nation or a nation-state or a multi-nation (Miller, 1995). As Loobuyk (this volume) puts it: 'distributive justice and deliberative democracy require that citizens share more than simply political principles, but less than a shared conception of the good life. A shared but 'thin' national identity should and can be sufficient'. The difference between this 'liberal national multiculturalism' and what Levey terms 'parity multiculturalism', however, is not seismic, and presents a smaller cleavage than that between Quebec and European conceptions of interculturalism.

This should not imply however that there are not significant differences between the liberal nationalist, interculturalist and multiculturalist camps. Like a Venn diagram they can simultaneously occupy common and distinct areas. If we take up Levey's (this volume) 
challenge of contrasting liberal nationalists with political multiculturalists, beyond the issue of majority precedence that he uses to distinguish the two, a number of observations can be made. It is clear that political multiculturalism can be more receptive to the place of religion in public life, or more precisely that religion is not precluded a priori on the grounds that it makes claims of a different order to those relating to ethnicity or culture. Furthermore, and in a manner that returns us to the discussion of the majority, the terms of common membership, especially - though not exclusively - in relation to national identity are deemed more fluid and changeable. Thirdly, and perhaps at a more foundational level, political multiculturalists such as Modood (2013) do not ground their politics in an ethics of autonomy, or certainly an ethic of individual autonomy. This joins together with a fourth concern relating to the capacity of communities and groups, and their roles in forging conceptions of the good life. Perhaps sharing something with McLaughlin (1992: 123) here too, the third and fourth distinction mean that multiculturalists, much more so than liberal nationalists consider there to be multiple launch pads for autonomy, in which 'a legitimate starting point is from the basis of experience of a particular 'world view' or cultural identity; a substantiality of belief, practice or value'.

Neither liberal nationalists nor interculturalists give religious groups the importance they give to ethnicity, preferring to leave new religions to prevailing norms of toleration within existing secularist arrangements - this is especially true in Quebec where some interculturalists respond by reaffirming a conception of laicite, or at least reinterpreting laicite as 'open secularism' (Bouchard this volume) - while others allow exemptions, for example in relation to the Sikh turban. Here some interculturalists and some multiculturalists also complement each other. Kymlicka's liberal secularism, for example, is quite consistent with this view (see also Meer and Modood, this volume). Yet here too our distinction between two modes of interculturalism is borne out further. For European interculturalists (see Cantle this volume) seek to change the frame from one of 
accommodating ethnoreligious groups to one of globalisation, young people, hybridity, cosmopolitanism, individualism, and so forth.

\section{Chapter Overviews}

This book explores the topics of interculturalism and multiculturalism, including their relationships to each other and to public philosophies more broadly. It commences with Meer and Modood's chapter which sets the challenge that constitutes this book, namely the relation between multiculturalism and interculturalism, specifically in identifying in what ways the latter is different from and/or an advance on multiculturalism. Meer and Modood critically examine some of the ways in which conceptions of interculturalism are being positively contrasted with multiculturalism, especially as political ideas. They argue that while some advocates of a political interculturalism wish to emphasise its positive qualities in terms of encouraging communication, recognising dynamic identities, promoting unity and critiquing illiberal cultural practices, each of these qualities too are important (on occasion foundational) features of multiculturalism. Importantly, they explore the provenance of multiculturalism as an intellectual tradition, with a view to assessing the extent to which its origins continue to shape its contemporary public 'identity' to show how some of the criticism of multiculturalism is rooted in an objection to earlier formulations that displayed precisely those elements deemed unsatisfactory when compared with interculturalism. They maintain, however, that interculturalism -as a political discourse does not, intellectually at least, eclipse multiculturalism, and so should be considered as complementary to multiculturalism.

To some extent Zapata-Barreo reframes this challenge in arguing that the multicultural debates of the late twentieth century tended to follow a cultural rights-based approach to 
diversity. He maintains that these were centred on questions such as the rights of cultural recognition in the public sphere, and how to reassess equality and cultural rights of nonnational citizens with different languages, religions, and cultural practices. This approach characterized multicultural citizenship studies until the emergence of a "new paradigm of interculturalism' which, in his reading, offers a lifeline to all those who see diversity as an asset in the public square. In providing a theoretically driven account of the intercultural turn', Zapata-Barrero proposes an over-arching political theory that can function as a normative framework.

In the first of our chapters tackling the interculturalism-multiculturalism nexus from a Quebec perspective, Gerard Bouchard returns us to the view that pluralism provides the general background of interculturalism, and which translates into respect for human rights, support for immigration, assistance to minority languages and cultures, wider practices of accommodation, and so forth. He moves on from this to insist that at the micro-level, a second defining trait of interculturalism is its emphasis on exchange and interaction between citizens of all origins, with a view to activating diversity as a resource, fighting stereotypes, avoiding 'groupism' and preventing social exclusion. His model of interculturalism, moreover, stresses integration as a two-way process but, in addition, is designed for societies where perceptions of ethno-cultural realities are structured on the basis of a majorityminorities relationship. In this view the protection of minority rights must be reconciled with majority rights, which also calls for some forms of ad hoc, contextual precedence in favour of the majority culture.

In the second of our readings of interculturalism from a Quebec context, Gagnon and Iacovino frame the merits of interculturalism as an explicit model for integration. They contrast this with how they see Canadian multiculturalism as being a product of nation- 
building efforts, rather than a genuine commitment to the main tenets of multiculturalism, they maintain, it is a framework for the promotion of cultural pluralism. They contend that a model of cultural pluralism along the lines of Quebec interculturalism makes a more serious effort to balance the requirements of unity with the preservation, recognition, and the flourishing of minority cultures. At the same time they note the enduring problem confronting the Quebec model, one that would have to be taken into account in any future attempts at empirical verification. Namely, the idea of competing interpretations of citizenship by those identified for integration in the first place. The Quebec model is, they maintain, placed to address this because it is embedded in a larger project for national affirmation. The fact that it can legitimately be included as a model for integration at the very least demonstrates the strides that Quebec has made in the area of citizenship.

A contrasting reading of interculturalism comes from Ted Cantle's contribution, and which begins with the view that multicultural policies, in Europe at least, are not fit for purpose and have slowed, if not inhibited, both integration and the acceptance of difference. Interculturalism for Cantle is based upon an entirely different conceptual and policy framework and offers a new and progressive approach to how we learn to live with diversity. In this view the Bouchard and also Gagon and Iacovino readings of interculturalism have been the most difficult to sustain because they mirror what he argues is a reified, static and defensive form of identity management in European forms of multiculturalism. Interestingly, Cantle sees the Canadian Government form of multiculturalism as being closer to the European idea of interculturalism. Cantle (2012: 79) nonetheless maintains that 'Interculturalism should...build upon the essential elements of multiculturalism - the framework of rights to equal treatment and non-discrimination are critical - as well as developing the interaction and belonging programmes initiated by community cohesion.' In this regard, while multiculturalism's focus on inequalities was justified, he argues it has failed to adapt to 'super-diversity' and the multi-faceted aspects of difference and 'otherness', 
including those based on disability, age, sexual orientation and gender - what we might otherwise call intersectionality. Further, for Cantle multiculturalism remained firmly rooted in intra-national differences, between minority and majority populations, and can be contrasted with interculturalism which recognises that 'difference' now crosses national boundaries and also reflects the heterogeneity of national, ethnic and faith groups.

These robust challenges are met with an equally vigorous rejoinder from Will Kymlicka. In his contribution Kymlicka argues that interculturalists may think that they are defending diversity, but their 'crude anti-multiculturalist rhetoric may play into the hands of xenophobes who reject both multiculturalism and interculturalism' (this volume). He focuses on the intercultural strategy to build a new political narrative in which interculturalism emerges from the alleged failed extremes multiculturalism. 'Can this new narrative work to energize pro-diversity forces and to undercut support for populism?', he asks. The answer is uncertain, for in his reading interculturalist narratives have too often left untouched exclusionary accounts of nationhood, and unintentionally legitimized populist narratives about the untrustworthy nature of mainstream elites on issues of diversity. In this respect, he concludes, 'the search for new narratives of diversity will have to continue'.

Stepping outside the North American-Western European nexus, Ana Solana's chapter brings in Latin American academic debates about multiculturalism, interculturalism, and interculturalidad, identifying patterns, similarities, and differences among them. Her chapter provides an introduction to a form of interculturalism, Latin American interculturalidad, which emerged not as a response to post-immigrant social formations but to colonial and post-colonial dynamics and relationships, including but not limited to indigenous groups. She argues that across the continent, academic discussions largely 'prescribe and dichotomize models of diversity' (this volume). In contrast, she advocates a 
contextual approach that opens up potential avenues for dialogue and cross-pollination. Focusing especially on how Latin American scholars define interculturalidad, and especially its capacity for 'equitable relations among members of different cultural universes' (Godennzi Alegre 1996: 15, in Solana this volume). There is however no one simple or agreed-upon definition of interculturalidad among scholars, particularly because interculturalidad in the Latin American context is conceived as a work in progress. The important acknowledgement is that interculturalism also exists in contexts other than North America (especially Canada) and Europe, and that emerges in contexts where multiculturalism has not been the predominant diversity paradigm. In these cases it is not necessarily a reaction to dissatisfaction presumably caused by multiculturalism, which means that interculturalidad in Latin America is not as recent as some scholars might assume.

Our final three papers return us to the theme of possible reconciliations between interculturalism and multiculturalism. In the first by Geoff Levey, we observe that the tensions between interculturalism and multiculturalism can also run across interculturalism and multiculturalism. So while the issue of 'ad hoc majority precedence' is central between multiculturalism and interculturalism, at least on the Québec model, in Levey's reading it also runs across liberal nationalist multiculturalism and parity multiculturalism too. The second, by Patrick Loobuyck, understands interculturalism neither as an antimulticulturalist position nor as a remedy for the alleged failures of multiculturalism, but instead as an additional strategy that might rest alongside modes of liberal nationalism and constitutional patriotism. The challenge that each sets itself, in this reading, is to create a sense of belonging as a necessary condition for solidarity and deliberative democracy in multicultural societies. Loobuyck understands this as presently expressed across three intercultural policy applications concerned with social mixing, language and civic integration programs, and integrative religious education respectively. In this account while 
multiculturalism and interculturalism do not contradict each other on the theoretical level, there may be some tensions on the policy level.

In the final chapter Modood, a European multiculturalist directly engages with Quebecan interculturalism. He acknowledges that Quebecan interculturalists have raised the question of the normative significance of the majority in the way that multiculturalists have not; and that multiculturalists can learn from those interculturalists. However, he holds that multiculturalists can take on board this concern with the majority without changing or amending multiculturalism. He accepts the starting-points of the 'ad hoc majority precedence' argument but not the conclusions. To underline the point he concludes by reaffirming a commitment to accommodate ethnoreligious minorities that is very different from what is advocated by Quebeckers. So, despite emphasising the overlaps and dialogical connexions between Quebecan interculturalism and multiculturalism as he understands it, he is of the view that they clearly differ on fundamentals too.

This indeed could also be said to be the message of the book: there are different versions of multiculturalism and interculturalism; within each set there are differences even while there is significant common ground across the two sets. This is a sentiment shared by Bhikhu Parekh, as stated in his afterword, whose own position is one which marries interculturalism and multiculturalism. He is nonetheless willing to acknowledge that there are some other things that we can learn from more recent interculturalist critics, while rejecting the view that multiculturalism is flawed and needs to be replaced or that intercultrualism is a successor position. In this respect there are not fundamental differences between the two 'isms'. So, that while interculturalisms add to multiculturalisms they do not always understand the latter, and certainly cannot be said to supersede political multiculturalism as 
it has been built up in theory and practice over the decades on both sides of the North Atlantic.

\section{Acknowledgements}

This edited collection includes papers first presented at a two day European Science Fund (ESF) exploratory Workshop organised by Ricard Zapata-Barrero and Tariq Modood, held in Barcelona. We would like to thank the ESF for their generous funding and support. The collection also incorporates some materials first developed in an earlier form in the Journal of Intercultural Studies, 33 (2), and we gratefully acknowledge that here. Ana SolonaCampos provided very helpful comments on an earlier draft, and Jenny Daly at Edinburgh University Press has provided excellent support throughout the review process and we would also like to thank her and EUP more broadly. Finally, we have been very fortunate to be able

to include a Foreword and Afterword respectively from Professor Charles Taylor and Professor Lord Bhikhu Parekh. We are delighted to include their participation.

\section{Bibliography}

Banting, K., \& Kymlicka, W. (2013) 'Is there really a retreat from multiculturalism policies? New evidence from the multiculturalism policy index', Comparative European Politics, 11, 577-598.

Bentley, A. (1948) The Process of Government. Evanston: Principia.

Berlin, I. (1991) The Crooked Timber of Humanity: chapters in the history of ideas. London: Fontana Press.

Berry, J. W., Phinney, J. S., Sam, D. L., and Vedder, . P (2006) 'Immigrant Youth: Acculturation, Identity and Adaptation', Applied Pychology: An International Review, 55 (3), pp: 303-332. 
Bloemraard, I. (2006) Becoming a Citizen: Incorporating Immigrants and Refugees in the United States and Canada. Berkeley: University of California Press.

Bloomfield J and Bianchini F (2004) Planning for the intercultural City. Stroud: Comedia.

Bouchard, G. (2011) ‘What is Interculturalism’, McGill Law Journal, 56 (2), 435-468.

Cantle, T. (2013) 'Interculturalism: what makes it distinctive?', in: M. Barrett (Ed) (2013) Interculturalism and Multiculturalism. Brussels: Council of Europe.

Cantle T. (2012), Interculturalism: the new era of cohesion and diversity, Palgrave Macmillan, Basingstoke.

Canovan, M. (1998) Nationhood and Political Theory. Edward Elgar.

Carbaugh, D. (2013) ‘On Dialogue Studies’, Journal of Intercultural Studies, 1 (1), 9-28.

Clarijs MAJL, Guidikova I (2011) Diversity and Community Development: An Intercultural Approach. Amsterdam: SWP.

Council of Europe (2008), White Paper on intercultural dialogue - Living together as equals in dignity', Committee of Ministers, Council of Europe, Strasbourg, www. coe.int/t/dg4/intercultural/source/white\%2opaper_final_revised_en.pdf, accessed 18 August 2009.

Dahl, R.A. (1961) Who Governs?: Democracy and Power in an American City, New Haven, CT: Yale University Press.

Froumin, I., 2003. Citizenship education and ethnic issues in Russia. In: J.A. Banks, ed. Diversity and citizenship education: global perspectives. San Francisco, CA: Jossey-Bass.

Gagnon, A.G. and Iacovino, R., (2007) Federalism, citizenship and Quebec: debating multinationalism. Toronto: University of Toronto Press. 
Guidikova, I. (2015) "Intercultural integration: a new paradigm for managing diversity as an advantage", In Interculturalism in Cities: Concept, Policy and Implementation, edited by R. Zapata-Barrero. Cheltenham: Edward-Elgar Publishing: 136-151

Guidikova, I. (2014) Cultural diversity and cities - the intercultural integaration approach. EUI: RSCAS Policy Paper 2014/o2

Habermas (1987) [1981]. Theory of Communicative Action Volume Two: Liveworld and System: A Critique of Functionalist Reason (Book). Translated by Thomas A. McCarthy. Boston, Mass.: Beacon Press

Hepburn, E,. and Zapata-Barrero, R. (eds.) (2014) The politics of Immigration in Multi-level States: Governance and Political Parties._Houndmills, Basingstoke: Palgrave MacmMillan.

James, M. R. (2003) 'Communicative Action, Strategic Action, and Inter-Group Dialogue', European Journal of Political Theory, 2 (2), 157-182.

Kymlicka, W. (2012) 'Multiculturalism: success, failure, and the future', in Migration Policy Institute (eds) Rethinking National Identity in the Age of Migration. Bielefeld: Verlag.

Luchtenberg, S. (2003) Migration, Education and Change. London: Routledge.

Maxwell B., Waddington D. J., McDonough K., Cormier A.-A. and Schwimmer M. (2012), 'Interculturalism, multiculturalism, and the state funding and regulation of conservative religious schools', Educational Theory, 62(4), pp. 427-447

McLaughlin, T. H. (1992) The ethics of separate schools, in: M. Leicester \& M. Taylor (Eds.), Ethics, ethnicity and education (London: Kegan Paul).

Meer, N. (2014) Race and Ethnicity: Key Concepts. London: Sage.

Meer, N. and Modood, T. (forthcoming) 'Religious pluralism in United States and Britain, its implications for Muslims and nationhood', Social Compass. 
Meer, N., Mouritsen, P., Faas, D., and de Witte, N. (2015) 'Examining post-multicultural and civic turns in the Netherlands, Britain, Germany and Denmark', American Behavioural Scientist.

Miller, D. (1995) On Nationality. Oxford: OUP.

Modood, T. (2014) 'Multiculturalism, Interculturalism and the Majority', Journal of Moral Education, 43, 302-315.

Modood, T. (2013) Multiculturalism: A Civic Idea. Cambridge: Polity Press.

Modood, T. and Meer, N. (2013) 'Multiculturalism', in The Oxford Companion to Comparative Politics. Oxford University Press

Parekh, B. (2000) Rethinking Multiculturalism. Basingstoke: Palgrave

Pécoud, A. and de Guchteneire, P. (2007) 'Introduction: the migration without border scenraio', in A. Pecoud and P. de Guchteneire (eds) Migration Without Borders: Essays on the Free Movement of People. Paris: UNESCO Publishing.

Pettirgrew, T. E., Tropp, L. R., Wagner, U. and Christ, O. (2011) 'Recent advances in intergroup contact theory', International Journal of Intercultural Relations, 35, 271-280.

Phillips, M., (2006) Londonistan: how Britain created a terror state within. London: Gibson Square Books.

Phipps, A. (2014) 'They are bombing us now', intercultural dialogue in times of crisis', Language and Intercultural Communication, 14:1, 108-124.

Prins, G. and Salisbury, R. (2008) 'Risk, threat and security - the case of the United Kingdom', RUSI journal, 22-27.

Potera, A. (2012) 'Intercultural Education and All-day Schools in Italy', in: N. Palaiologou and G. Dietz (2012) Mapping the Broad Field of Multicultural and Intercultural Education 
Worldwide: Towards the Development of a New Citizen. Newcastle: Cambridge Scholars Publishing.

Taylor, C. (2001) 'Multiculturalism and political identity', Ethnicities, 1: 122-8.

Toynbee, A. (1958) Christianity among the religions of the world. London: Oxford University Press.

Tremblay, L. B. (2009) The Bouchard-Taylor Report on Cultural and Religious Accommodation: Multiculturalism by Any Other Name? EUI Law Working Papers; 2009/18: http://cadmus.eui.eu/handle/1814/12971

Tubino, F. (2013) 'Intercultural practices in Latin American Nation States', Journal of Intercultural Studies, 34 (5), 604-619.

Tully, J. (2002) 'The illiberal liberal', in: P. Kelly (Ed). Multiculturalism reconsidered. Cambridge: Polity.

UNESCO (2008) World Report on Cultural Diversity (Paris: UNESCO).

Vertovec, S. (1999) 'Conceiving and researching transnationalism', Ethnic and Racial Studies, 22 (2): 1-24

Vertovec, S., \& Wessendorf, S. (Eds.). (2010). The multiculturalism backlash: European discourses, policies and practices. London: Routledge.

Walzer, M. (1997) On Tolerance. New Haven: Yale University Press

Weller, P. (2012) 'The End of Multiculturalism? A Riposte', in: Dialogue Society (eds) Debating Multiculturalism I. London: Dialogue Society.

Wilson, R. (2013) 'The urgency of intercultural dialogue in a Europe of insecurity', in: M. Barrett (Ed) (2013) Interculturalism and Multiculturalism. Brussels: Council of Europe. 
Wood P (2004) The Intercultural City Reader. Stroud: Comedia

Wood, P. (2015). 'Meet me on the Corner? Shaping the conditions for cross-cultural interaction in urban public space', in: R. Zapata-Barrero (Ed.) Interculturalism in Cities: Concept, Policy and Implementation. Cheltenham: Edward-Elgar Publishing: 53-75.

Zapata-Barrero, R. (2015a) 'Introduction: Framing the intercultural turn', in: Interculturalism in Cities: Concept, Policy and Implementation, edited by Zapata-Barrero. Cheltenham: Edward-Elgar Publishing; viii-xvi

Zapata-Barrero, R. (2015b) 'Exploring the foundations of the intercultural policy paradigm: a comprehensive approach', Identities: Global Studies in Culture and Power, 22, Issue 1.

Zapata-Barrero, R. (2009) (ed.) Immigration and self-government of minority nations, Brussels: Peter Lang. 